\title{
Chemical composition of leaf essential oil of Annona senegalensis Pers. (Annonaceae) growing in North Central Nigeria
}

\author{
O. M. AMEEN ${ }^{1 *}$, L. A. USMAN ${ }^{1}$, F. S. OGANIJA ${ }^{1}$, A. A. HAMID ${ }^{1}$, \\ N. O. MUHAMMED ${ }^{2}$, M. F. ZUBAIR ${ }^{1}$ and S. A. ADEBAYO ${ }^{1}$ \\ ${ }^{1}$ Department of Chemistry, University of Ilorin, PMB 1515, Ilorin, Nigeria. \\ ${ }^{2}$ Department of Biochemistry, University of Ilorin, PMB 1515, Ilorin, Nigeria. \\ *Corresponding author, E-mail: moameen@unilorin.edu.ng; Tel +2348035019199
}

\begin{abstract}
Leaf essential oil of Annona senegalensis Pers. obtained by hydrodistillation was analysed using GC and GC/MS. The analyses revealed the abundance of oxygenated monoterpenes $(65.0 \%)$. The major constituents were citronellal (30.0\%), citronellol (14.8\%), geranial (17.2\%), thymol $(8.1 \%), \beta$ - caryophyllene (7.8\%) and carvacrol $(6.92 \%)$.

(C) 2011 International Formulae Group. All rights reserved.
\end{abstract}

Keywords: Annonaceae, Annona senegalensis, citronellal, citronellol, geranial, thymol.

\section{INTRODUCTION}

Annona senegalensis Pers. (Annonaceae) is a perennial shrub widely grown in Nigeria where it is commonly known as gwandar daaji among the Hausa speaking people and abo, ewe-aso by the Yorubas (Pinto et al., 2005; Suleiman et al., 2008; Kayode et al., 2009; Orwa et al., 2009).

The plant is used in folk medicine for the treatment of several ailments like guinea worm, diarrhoea, snakebite, headache and respiratory infections. The leaves are used for treating pneumonia, while gum from the bark is used in sealing cuts and wound (Orwa et al., 2009). The biological activities of the plant extract reported by various workers justified the use of the plant in traditional medicine. For instance, the plant extract were found to possess antimalarial, antidiarrhoea, antibacterial and anthelmintic properties (Alawa et al., 2003; Ajaiyeoba et al., 2006; Apak and Otila, 2006; Suleiman et al., 2008). The larvicidal, trypanocidal and cytotoxic properties of the extract have also been reported (Ajaiyeoba et al., 2006; Ogbadoyi et al., 2007; Magadula et al., 2009).

Phytochemical investigations of the plant led to the isolation of (-) - roemerine (You et al., 1995; Magadula et al., 2009) and ent-kaurene diterpenoids (Fatope et al., 1996). Similarly, p-cymene has been reported as the most abundant component of the stem bark essential oil of A. Senegalensis grown in Democratic Republic of Congo (DRC) (Farid et al., 2002). Germacrene D was reported to be the predominant constituent of the leaf essential oil obtained from Burkina Faso grown A. senegalensis (Nebie et al., 2005), while analysis of the seed oil obtained from 
Senegal grown A. senegalensis showed the predominance of terpinen-4-ol (Alassane et al., 2004). Earlier work on the leaves and fruits essential oil of the plant growing in South-West Nigeria also revealed the presence of car-3-ene and linalool as the major constituent of the fruit and leaf oils respectively (Ekundayo and Oguntimehin, 1986).

Variations in composition pattern of essential oil from the same plant species have been attributed to agro climatic and geographical conditions (Lahlou, 2004). It is on this basis, that we investigate the leaf essential oil of North Central Nigerian grown A. senegalensis.

\section{MATERIALS AND METHODS}

\section{Plant materials}

The fresh leaves of Annona senegalensis were obtained in Ilorin, Kwara State, Nigeria. Identification and authentication were carried out at the herbarium of Forestry Research Institute of Nigeria (FRIN), Ibadan, where voucher specimen was deposited.

\section{Oil isolation}

Pulverized leaves of the plant were hydrodistilled for $3 \mathrm{~h}$ in a Clevenger-type apparatus, according to the British Pharmacopoeia (1980) specification. The resulting oil was collected, preserved in a sealed sample tube and stored under refrigeration until analysis.

\section{Gas chromatography}

GC analysis was performed on an orion micromat 412 double focusing gas chromatography system fitted with two capillary columns coated with CP - Sil 5 and CP - Sil 19 (fused silica, $25 \mathrm{~m} \times 0.25 \mathrm{~mm}$, $0.15 \mu \mathrm{m}$ film thickness) and flame ionization detector (FID). The volume injected was 0.2 $\mu \mathrm{L}$ and the split ratio was 1:30. Oven temperature was programmed from $50-230$ ${ }^{\circ} \mathrm{C}$ respectively. Qualitative data were obtained by electronic integration of FID area without the use of correction factors.

\section{Gas chromatography/mass spectrometry}

A Hewlett Packard (HP 5890A) GC interfaced with a VG Analytical 70 - $250 \mathrm{~S}$ double focusing mass spectrometer was used. Helium was the carrier gas at $1.2 \mathrm{ml} / \mathrm{min}$. The MS operating conditions were: ionization voltage $70 \mathrm{ev}$, ion source temperature $230{ }^{\circ} \mathrm{C}$. The GC was fitted with a $25 \mathrm{~m} \times 0.25 \mathrm{~mm}$, fused silica capillary column coated with $\mathrm{CP}$ Sil 5. The film thickness was $0.15 \mu \mathrm{m}$. The GC operating conditions were identical with those of GC analysis. The MS data were acquired and processed by online desktop computer equipped with disk memory. The percentage compositions of the oil were computed in each case from GC peak areas. The identification of the components was based on the retention indices (determined relative to the retention times of series of nalkanes) and mass spectra with those of authentic samples and with data from Literature (Jennings and Shibamito, 1980; Adams, 1995; Joulain and Koenig, 1998).

\section{RESULTS AND DISCUSSION}

Pulverised leaves of Annona senegalensis afforded $0.02 \% \mathrm{v} / \mathrm{w}$ of essential oil. The yield compared favourably with the yield obtained from the leaf of $A$. senegalensis grown in South West Nigeria (Ekundayo and Oguntimehin, 1986). Table 1 shows the retention indices, relative percentage and identities of the constituents of the oil. A total of 36 compounds representing $97.2 \%$ of the oil were identified.

The oil was characterised by the abundance of oxygenated monoterpenes $(65.0 \%)$. Aromatic compounds and hydrocarbon monoterpenes constituted 15.0 and $10.9 \%$ of the oil respectively. The percentage composition of hydrocarbon sesquiterpenes was $7.8 \%$. Predominant oxygenated monoterpenes in the oil were citronellal $(30.0 \%)$, geranial $(17.2 \%)$, citronellol (14.8\%) and linalool (2.8\%). Aromatic compounds that were found as the principal constituents of the oil include thymol (8.1\%) and carvacrol (5.4\%). 
Table 1: Chemical composition (\%) of the leaf oil of A. senegalensis.

\begin{tabular}{|c|c|c|c|}
\hline Compound $^{\text {a }}$ & $\mathbf{R I}^{\mathbf{b}}$ & $\%$ Composition & Mass Spectra Data \\
\hline$\alpha$-thujene & 926 & $\operatorname{tr}$ & $91,105,121,136$ \\
\hline$\alpha$-pinene & 933 & 0.1 & $69,79,93,121,136$ \\
\hline$\beta$-pinene & 976 & 0.1 & $77,93,107,121,136$ \\
\hline Myrcene & 990 & 10.9 & $93,107,115,121,136$ \\
\hline Cymene & 1022 & $\operatorname{tr}$ & $41,51,58,119,134$ \\
\hline Benzyl alcohol & 1028 & $\operatorname{tr}$ & $51,65,73,79,91,108$ \\
\hline 1,8 -cineole & 1029 & $\operatorname{tr}$ & $81,108,129,139,154$ \\
\hline Cis-ocimene & 1035 & $\operatorname{tr}$ & $78,93,105,121,136$ \\
\hline$\gamma$-terpinene & 1057 & $\operatorname{tr}$ & $41,51,73,105,121$ \\
\hline Iso-Artemisia & 1057 & $\operatorname{tr}$ & $41,55,69,83,91$ \\
\hline Linalool & 1098 & 2.8 & $43,67,80,97,121,137$ \\
\hline Pinine-2-ol & 1136 & $\operatorname{tr}$ & $55,69,79,111,139$ \\
\hline Allo ocimene & 1142 & $\operatorname{tr}$ & $67,79,91,105,121,139$ \\
\hline Citronellal & 1150 & 30.0 & $41,55,69,81,121,136$ \\
\hline Borneol & 1162 & $\operatorname{tr}$ & $67,81,95,110,121$ \\
\hline Terpinen-4-ol & 1175 & $\operatorname{tr}$ & $43,111,125,136,154$ \\
\hline$\alpha$-terpineol & 1188 & $\operatorname{tr}$ & $59,81,93,107,121,139$ \\
\hline Citronellol & 1226 & 14.8 & $41,55,69,109,138$ \\
\hline Neral & 1236 & $\operatorname{tr}$ & $69,95,109,119,135$ \\
\hline Linalyl acetate & 1255 & 0.2 & $43,55,93,105,121$ \\
\hline Geranial & 1268 & 17.2 & $53,69,83,95,99,109$ \\
\hline Borneol acetate & 1284 & $\operatorname{Tr}$ & $67,80,95,108,121,136$ \\
\hline Thymol & 1290 & 8.1 & $65,77,91,135,150$ \\
\hline Carvacrol & 1299 & 5.4 & $41,51,65,135,150$ \\
\hline$\beta$-elemene & 1300 & $\operatorname{tr}$ & $150,165,177,193,208$ \\
\hline$\alpha-$ copaene & 1375 & $\operatorname{tr}$ & $105,119,161,189,204$ \\
\hline$\beta$-caryophyllene & 1418 & 7.8 & $79,91,105,119,133$ \\
\hline Ethyl cinnamate & 1460 & $\operatorname{tr}$ & $79,91,105,119,133,147$ \\
\hline Germacrene D & 1490 & $\operatorname{tr}$ & $91,105,133,147,204$ \\
\hline Bicyclogermacrene & 1494 & $\operatorname{tr}$ & $67,79,93,107,121$ \\
\hline$\beta$-bisabolene & 1509 & $\operatorname{tr}$ & $53,69,79,93,105$ \\
\hline Acetyleugenol & 1523 & $\operatorname{tr}$ & $121,131,149,164,207$ \\
\hline Elemicin & 1553 & $\operatorname{tr}$ & $150,165,177,193,208$ \\
\hline Viridiflorol & 1589 & $\operatorname{tr}$ & $109,149,161,189,205$ \\
\hline Torreyol & 1643 & $\operatorname{tr}$ & $105,119,133,161,204$ \\
\hline Benzyl benzoate & 1761 & $\operatorname{tr}$ & $51,65,77,91,105,152$ \\
\hline Total & & 97.2 & \\
\hline
\end{tabular}

The most abundant hydrocarbon monoterpenes was myrcene $(10.7 \%)$, while $\beta$ caryophyllene was the only hydrocarbon sesquiterpene found in significant proportion in the oil. $\beta$-elemene, $\alpha$-copaene, germacrene and $\beta$-bisabolene were detected in trace amounts.

Comparison of the composition pattern of the oil, with the oil obtained from south west grown $A$. senegalensis revealed both 
qualitative and quantitative differences. For instance, oxygenated monoterpenes constituted $65 \%$ of the oil while the oil obtained from the leaf of South-West grown A.senegalenses was constituted by $19.5 \%$ of oxygenated monoterpenes. The principal oxygenated monoterpenes, citronellal, citronellol and geranial in the oil were not detected in the oil obtained from South West grown A. senegalensis (Ekundayo and Oguntimehin, 1986). Similarly, geraniol, one of the principal constituents of South West grown A. senegalensis was not detected in North Central grown A. senegalensis. Meanwhile, a bicyclic monoterpene; car-3ene that was detected in the leaf oil of south west grown A. senegalensis was not found in this study. In addition, carvacrol and thymol, the most predominant aromatic compounds in the oil were not found in the oil obtained from south west grown A. senegalensis.

On the other hand, the most abundant constituent of the leaf oil of south west grown A. Senegalensis, linalool, was found in appreciable quantity in the leaf oil of North Central grown A. senegalensis. Hence, the oil of South-West grown A. senegalensis is of linalool chemotype. Meanwhile, the most abundant compound in the oil of North Central grown A. senegalensis is citronellal, thus, the oil is of citronellal chemotype.

Variation in composition patterns of the oil from the two locations may be due to agroclimatic and geographical conditions.

\section{REFERENCES}

Adams RP. 1995. Identification of Essential Oil Components by Gas Chromatography and Mass Spectrometry. Allured Publ. Corp., Carol Stream, IL.

Ajaiyeoba E, Falade M, Ogbole O, Okpako L, Akinboye D. 2006. In vivo antimalarial and cytotoxic properties of Annona senegalensis extract. Afr. J. Trad. CAM, 3(1): 137 - 141.

Alassane W, Idrissa N, Mamadou B. 2004. Fatty acid and essential oil compositions of the seed oil of five Annona species. Nig. J. Nat. Prod. and Med., 8: $62-65$.

Alawa CBI, Adamu AM, Gefu JO, Ajanusi OJ, Abdu PA, Chiezey NP, Alawa JN, Bowman DD. 2003. In - vitro screening of Nigerian medicinal (Vernonia amygdalina and Annona senegalensis) for anthelmintic activity. Veterinary Parasitology, 113(1), 73 - 81.

Apak L, Otila D. 2006. The in vitro antibacterial activity of Annona senegalensis, Securidacca longipendiculata and Steganotaenia araliacea Ugandan medicinal plants. African Health Sciences, 6(1): $31-34$.

British Pharmacopoeia II. 1980. 109, H M, Stationary Office, London.

de Q Pinto AC, Cordeiro MCR, de Andrade SRM, Ferreira FR, de C Filgueiras HA, Alves RE, Kinpara DI. 2005. Annona Species. International Centre for Underutilised Crops. University of Southampton, Southampton, UK, pp 21 24.

Ekundayo O, Oguntimehin B. 1986. Composition of the essential oils of Annona senegalensis var senegalensis, Palnta Med., 52(3): 202 - 204.

Farid K, Chafique Y, Rachid S, Jean MB. 2002. Chemical composition of the essential oils of Annona cuneata L. and Annona senegalensis Pers. stem barks. Flavour and Fragrances, 17(5): 398 400.

Fatope MO, Audu OT, Takeda Y, Zeng L, Shi G, Shimada H, McLaughlin JL. 1996. Bioactive ent-Kaurene Diterpenoids from Annona senegalensis. J. Nat. Prod., 59(3): $301-303$.

Jennings W, Shibamito I. 1980. Qualitative Analysis of Flavour Volatiles by Gas Capillary Chromatography. Academic Press, New York.

Joulain D, Koenig WA. 1998. The Atlas of Spectra Data of Sequiterpene Hydrocarbons. E.B. Verlag: Hamburg, Germany. 
Kayode J, Jose RA, Ige OE. 2009. Conservation and Biodiversity Erosion in Ondo State, Nigeria: (4). Assessing Botanicals Used in the Cure of Sexually Transmitted Diseases in Owo Region. Ethnobotanical Leaflets, 13: 734-38.

Lahlou M. 2004. Methods to Study the Phytochemistry and Bioactivity of Essential Oil. Phytother. Res., 18: 435448.

Magadula JJ, Innocent E, Otiewo JN. 2009. Mosquito larvicidal and cytotoxic activities of 3 Annona species and isolation of active principles, Journal of Medicinal Plants Research, 3(9): 674 680.

Nebie RHCh, Yameogo RT, Belanger A, Sib FS. 2005. Chemical composition of leaf essential oil of Annona senegalensis Pers. from Burkina Faso. Journal of Essential Oil Research, 17(3): 331 - 332.

Ogbadoyi EO, Abdulganiy AO, Adama TZ, Okogun JI. 2007. In vivo trypanocidal activity of Annona senegalensis Pers. leaf extract against Trypannosoma brucei brucei. J. Ethnopharmacol., 112(1): 85 89.
Orwa C, Mutua A, Kindt R, Jamnadas R, Anthony S. 2009. Agroforestree Database: a tree reference and selection guide version 4.0, available at http://www.worldagroforestry.org/sites/tr eedbs/treedatabase.asp

Suleiman MM, Dzenda T, Sanni CA. 2008. Antidiarrhoeal activity of the methanol stem-bark extract of Annona senegalensis Pers. (Annonaceae). Journal of Ethnopharmacology, 116(1): 125-130. Also available at http://www.elsevier. com/locate/jethpharm, retrieved on 23/03/2010.

You M, Wickramaratne DB, Silva GL, Chai $\mathrm{H}$, Chagwedera TE, Farnsworth NR, Cordell GA, Kinghorn AD, Pezzato M. 1995. (-) - Roemerine, an aporphine alkaloid from Annona senegalensis that reverses the multidrug - resistance phenotype with cultured cells. J. Nat. Prod., 58(4): 598 - 604. 